DOI 10.18551/rjoas.2019-11.12

\title{
THE ROLE OF PROFITABILITY IN MEDIATING EFFECT OF LIQUIDITY, CAPITAL STRUCTURE, AND SALES GROWTH ON CORPORATE VALUE IN MANUFACTURING COMPANIES OF INDONESIA STOCK EXCHANGE
}

\author{
Andayani Ni Komang Mei ${ }^{\star}$, Purbawangsa Ida Bagus Anom \\ Faculty of Economics and Business, University of Udayana, Bali, Indonesia \\ ${ }^{\star}$ E-mail: mei.andayani77@gmail.com
}

\begin{abstract}
Company performance is one of the important factors to increase company value. Investor may invest easily if the value of the company increases. The key to increase company value are seen from various factors, ranging from liquidity, capital structure, and sales growth. The population of this study is manufacturing companies listed on the Stock Exchange for the period 2015-2017. The sample used in this study amounted to 109 companies using purposive sampling method. This study uses Path Analysis techniques and Sobel Test.The results of this study shows that liquidity and sales growth have no impact to firm value. Capital structure has negative and significant effect on company value. Profitability has a positive effect on company value. The result of the sobel test in this study revealed that profitability able to mediate capital structure, but, different result that profitability still cannot mediate the liquidity and growth sales of the company.
\end{abstract}

\section{KEY WORDS}

Firm value, profitability, liquidity, capital structure, growth sales.

The purpose of establishing a company is to maximize the value of the company. Decisions taken by company management refer to the main goal of maximizing the value of the company or the value of the firm (Asri, 2013). Maximizing the value of a company also means maximizing the welfare of shareholders. One of the goals of the company according to the theory of the firm is to maximize the prosperity of the owner or shareholders through increasing the value of the company (Hermuningsih, 2013). The value of a company is reflected in the share price of a company in a certain period, which is associated with investors' perceptions as the company's success rate. The value of the company is very important because the high value of the company will be followed by the high prosperity of shareholders (Brigham, 2013). Company value according to (Brigham, 2013) can be measured by price to book value (PBV), which is a comparison between stock prices and book values per share. PBV can be interpreted as the result of a comparison between the stock market price and the book value of shares. Husan and Satria (2019) argue that the company's value is the price that prospective buyers or investors are willing to pay when the company is sold. Keown et al. (2015: 470) states that the value of the company is the market value of the debt securities and corporate equity in circulation. Company value is an investor's perception of the company's success in managing resources. Several factors can affect the value of the company based on previous research conducted (Hermuningsih, 2013) including profitability, liquidity, sales growth, capital structure. Corporate financial decisions, one of which is a decision regarding capital structure will have an impact on the value of the company (Sinha, 2017). Capital structure according to Agnes Sawir (2015: 10) is permanent funding consisting of long-term debt, preferred shares, and shareholder capital. Modligiani \& Miller (1963) states that a company that has a high capital structure is a company that has a high level of debt compared to total equity. Debts held by companies will incur interest costs which in turn reduce taxes. According to Herry Subagyo (2011) states that the use of debt is only effective in increasing the value of the company when investment opportunities are low, if investment opportunities are high the use of debt will negatively affect the value of the company. Murtianingsih's research (2012) also states that capital structure influences but is not significant to firm value, this can be interpreted that company 
value is more influenced by other indicators such as market sentiment or other factors.

Based on this study the profitability, liquidity, sales growth and capital structure variables are signaling theories. Signaling theory according to (Brigham and Daveys, 2016: 707) a sign or signal is an action taken by the company to provide instructions for investors about how management views the company's prospects. This signal theory is based on the assumption that managers and shareholders do not have access to the same company information. Based on signal theory, profitability is one of the important information for investors which is expected to be able to analyze the development of company profitability.

Profitability is the company's ability to generate profits in a certain period. Profitability is a measure of financial performance that is often used within a company. The profitability measurement ratio used is ROA (Return on Assets). Brigham and Daveys (2016: 32) define profitability as the end result of a number of company management policies and decisions. Company profitability is the company's ability to generate profits from investments that are invested in a certain period.

Profitability will affect a company's stock price in the future because profitability reflects the company's ability to generate profits which are investors' reference for investing or not (Lamuda, 2017). The development of research models in the field of financial management today, in general the dimension of profitability has a causal relationship to firm value. The company's value can be conceptually explained by the value reflected by the price of shares traded on the capital market. This causal relationship shows that if the company's management performance measured using profitability increases, it will have a positive impact on investors' decisions in the capital market to invest their capital in the form of equity participation, so will also have an impact on the decisions of creditors in relation to corporate funding through debt (Harmono, 2015).

Profitability in measuring financial performance consists of several proxies including Return on Assets (ROA), Return on Equity (ROE), Return on Investment (ROI), Gross Profit Margin (GPM), Net Profit Margin (NPM) (Kasmir, 2014). This study uses ROA in measuring company profitability, because ROA is a relevant measure of operating efficiency, namely the rate of return achieved by a company over the use of assets. The greater the value of ROA, shows the company's performance is getting better and in the end the value of the company will increase as well.

Su'aidah (2010), in his research on companies listed on the Indonesia Stock Exchange LQ-45 index category in 2005-2008 found that ROA had a positive and significant effect on firm value. This research is supported by research conducted by Anwar and Masodah (2012) in his research conducted on LQ-45 companies listed on the Indonesia Stock Exchange (BEI) in 2010-2011, which states that ROA has a significant effect on firm value. Wahyuningsih and Triyono (2016), Julianti (2016) and Komariyah (2015) also found that Return on Assets (ROA) had a positive and significant effect on firm value. In contrast to previous research conducted by Carningsih (2009) who used property and real estate companies listed on the Indonesia Stock Exchange (BEI) in 2007-2008, found that ROA has a negative effect on firm value.

Lamuda (2017) states that profitability ratios will show the effects of liquidity, asset management and debt on operating results. This ratio is used to determine the company's ability to generate profits or how effective management of the company is by management. Companies to be able to carry on his life, must be in a favorable condition. Companies that are in an unfavorable condition, it will be difficult for companies to obtain loans from creditors or investments from outside parties. According to Sartono (2014: 122) that profitability is the ability of a company to generate profits (profit) at a certain level of sales, assets and capital. Profitability ratios are used to show the combined effect of liquidity, asset management and debt on operating results (Brigham and Ehrhardt, 2014: 107). Based on the above definition, profitability is the company's ability to generate profits through the level of sales, capital invested, debt used by the company and assets owned. Profitability can be determined from the liquidity ratio, capital structure (debt and assets) and sales growth. This study uses liquidity ratios, capital structure and sales growth in influencing profitability and the effect of profitability on firm value. 
Liquidity is an indicator that measures a company's ability to pay or pay off all shortterm liabilities at maturity using available current assets (Janjua et al., 2016). Kasmir (2014: 128) believes that the liquidity ratio is a company's ability to measure the liquidity of a company's financial condition. The liquidity ratio according to Hery (2015: 149) is a ratio that shows the company's ability to meet obligations or pay short-term debt.

The types of liquidity ratios are: current ratio, quick ratio and cash ratio (Durrah et al, 2016). This study will use the current ratio as an indicator in determining the value of company liquidity. The use of the current ratio as an indicator of the liquidity ratio because the ratio is a ratio that measures the level of the company's ability to meet short-term obligations that have matured when billed as a whole. This ability reflects a positive financial performance where one of them is caused by the profitability of the company's activities

The greater value of the current ratio indicates that the company's profitability will increase. Great profitability indicates the greater ability of companies to meet short-term obligations or better liquidity (Durrah et al, 2016). Yuniari and Badjra (2019) in their research on the banking sector found that liquidity had a positive and significant effect on profitability. The research was also supported by research conducted by Meidiyustiani (2016) and Sejati (2014) who found that liquidity had a positive effect on profitability.

The effect of liquidity on firm value is supported by research conducted by Pasaribu (2008) and Rompas (2013) which found that liquidity has a significant effect on firm value. Research conducted by Jantana (2013) found that liquidity had a positive and significant effect on firm value in the consumer goods sector of the cigarette subsector on the Indonesia Stock Exchange in 2007-2011.

The company's performance is also determined by the capital structure that directly impacts the company's financial position and influences its profitability (Violita and Sulasmiyati, 2017). The capital structure is related to the amount of debt and own capital used to finance the company's assets. An optimal capital structure can create a strong and stable financial condition. Companies can assess their performance and make decisions for expansion by looking at the capital structure (Cipto et al., 2019). The consideration between foreign capital and own capital is referred to as the capital structure (Singh, 2016). Capital structure theory explains the effect of changes in capital structure on firm value. This theory links the company's long-term funding policy, which is a ratio between long-term debt and equity that aims to maximize the value of the company.

Babu and Jain (1998) state four reasons why companies prefer to use debt rather than new shares, namely (1) There are tax benefits on interest payments; (2) Transaction costs of debt issuance are cheaper than transaction costs of new share issuance; (3) It is easier to get debt funding than stock funding; (4) Management control is greater for new debt than for new shares. Debt issuance is a signal of good news that managers are more confident of the company's performance in the future so that stock prices increase with the announcement of an increase in debt. Rising stock prices reflect an increase in company value. Debt policies include corporate funding policies sourced externally (Arif, 2018).

Capital structure can be defined as permanent funding consisting of long-term debt, preferred shares and shareholder capital (Fajriati, 2017). Modigliani and Miller, (1963: 53) state the value of a company is determined by the capital structure. Several studies have shown that capital structure influences financial performance and firm value. Christi et al. (2013), Ahmad et al. (2013), Ebrati et al. (2013), Leon (2013), Mahmudi and Mohamadi (2015), Mujahid et al. (2015), Negasa (2016), shows that capital structure has a positive and significant effect on profitability. In contrast to the results of research conducted by Leon (2013), Pung and Hoang (2013), Quang and Xin (2014), Zakaria et al. (2014) and Christi et al. (2013) which shows that capital structure has a significant negative effect on profitability. Investors who do not like risk, will avoid stocks that have a high debt to asset ratio (DAR) value. Empirical evidence shows that DAR has a positive influence on stock returns, as evidenced by research conducted by Isshaq et al. (2009), Ebrati et al. (2013), Hasan et al. (2013) which states that capital structure has a positive and significant effect on firm value. The research was carried out by Ruan et al. (2011), Pung and Hoang (2013) show the opposite result where capital structure has a negative effect on firm value. Research Meca et 
al. (2011) and Mumtaz et al. (2013) also found that capital structure had no effect on firm value.

Sales is an important criterion for assessing a company's profitability and is a key indicator of company activity (Bachimeg, 2017). Companies with relatively stable sales can get more loans than companies with unstable sales (Brigham and Daveys, 2016: 513). Fast growing companies tend to use more debt to finance their business activities than companies that grow slowly (Hedau, et al. 2018).

Sales growth is an increase in sales between the current years compared to the previous year expressed as a percentage (Carvalho \& Costa, 2014). Sambharakreshna (2010) revealed that sales growth reflects the company's success in investments made in the past period, so that it can predict the company's growth in the future. The role of growth for companies is that an efficient company in growth can survive because it reflects a high level of business activity (Agiomirgianakis, Voulgaris \& Papadogonas, 2006). The company must manage its resources to generate revenue through sales (Sambharakreshna, 2010). Sales growth is also an indicator of demand (Sambharakreshna, 2010). The results of research conducted by Farhana (2016), Suryaputra and Christiawan (2016) show that sales growth has a positive and significant effect on profitability. Empirical evidence shows sales growth has a positive and significant effect on firm value (Pantaw et al. 2015). Sriwardany's research (2006) also found that sales growth had a positive and significant effect on increasing stock prices so that the company's value increased. Research by Cheng et al. (2010) found that sales growth had a positive effect on firm value. In contrast to the results of research conducted by Hermuningsih (2013), Safrida (2008) shows the opposite result that sales growth has no effect on firm value.

This research was conducted in manufacturing companies listed on the Indonesia Stock Exchange (IDX). The manufacturing industry in Indonesia is one of the industries with great potential. Based on data released by the United Nations Statistics Division in 2016, Indonesia ranks fourth in the world from 15 countries whose manufacturing industries contribute to the Gross Domestic Product (GDP) of more than 10 percent. Indonesia is able to contribute up to 22 percent after South Korea (29 percent), China (27 percent), and Germany (23 percent) (www.investindonesia.go.id.). Indonesia has become the largest manufacturing industry base in ASEAN. The development of the manufacturing industry in Indonesia is currently able to shift the role of commodity-based to manufacture-based (www.kemenperin.go.id).

IDX itself is a capital market in Indonesia which is "a party that organizes and provides and or a means to bring together the sale and purchase offers of other parties with the aim of trading securities between them" (Capital Market Law No. 8 of 1995 concerning BEI). In 2015 the number of companies listing (issuers) on the IDX was 509 companies, 141 of which were manufacturing companies or $27.70 \%$. While in 2016 there were 525 companies with 143 manufacturing companies or 27.23\%. In 2017 there were 539 companies with 147 manufacturers or $27.27 \%$ (www.idx.go.id). Of the 9 (nine) sectors found on the IDX, the manufacturing sector is the sector with the most companies, so manufacturing companies are suitable to be sampled in this study.

The potential of Indonesian manufacturing companies shows a good level of sales and is a source of profit. A description of profitability, company value and number of shares outstanding on companies listed on the Indonesia Stock Exchange (BEI) from 2015 to 2017, specifically the manufacturing sector which is the sector with the largest number of issuers can be presented in Table 1.

Table 1 - Profitability, Firm Value and Number of Outstanding Shares In Manufacturing Sector Companies Listed on the IDX 2015 to 2017

\begin{tabular}{llll}
\hline \multicolumn{1}{c}{$\mathrm{n} / \mathrm{n}$} & 2015 & 2016 & 2017 \\
\hline Profitability (ROA) & 0,031 & 0,045 & 0,042 \\
Corporate Value (average stock price) (Rp.) & 4.142 & 3.064 & 3.013 \\
Number of shares outstanding (sheets) & 3.708 .674 & 3.880 .153 & 3.907 .634 \\
\hline
\end{tabular}

Source: www.idx.go.id, Data Processed, 2018. 
Based on Table 1, it shows that profitability as measured by return on assets (ROA) in manufacturing sector companies listed on the IDX fluctuates. The value of the company as measured by the closing price of the company's shares in the same sector decreased from 2015 to 2017.

Based on several previous studies regarding the effect of liquidity, capital structure and sales growth on firm value, there are inconsistencies where there are studies that show positive results and also negative results. The phenomenon and differences in the results of previous studies related to the effect of liquidity, capital structure, sales growth on firm value, provide a gap for this research to reexamine the effect of liquidity, capital structure and sales growth on firm value. This study includes profitability as a mediating variable, because profitability is able to foster investor confidence which is the most important factor for increasing company value (Lubis et al. 2017).

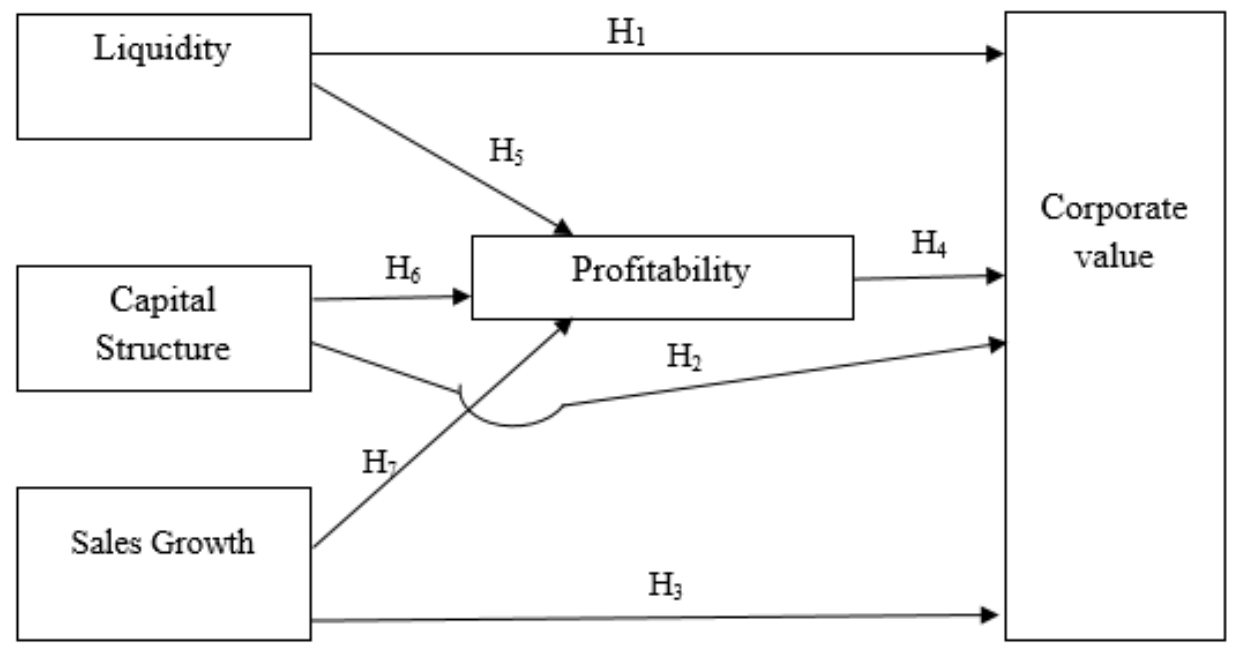

$\mathrm{H}_{1}$ : Liquidity has a positive and significant effect on the value of manufacturing companies listed on the Indonesia Stock Exchange;

$\mathrm{H}_{2:}$ Capital structure has a positive and significant effect on the value of manufacturing companies listed on the Indonesia Stock Exchange;

$\mathrm{H}_{3}$ : Sales growth has a positive and significant effect on the value of manufacturing companies listed on the Indonesia Stock Exchange;

$\mathrm{H}_{4 \text { : }}$ Profitability has a positive and significant effect on the value of manufacturing companies listed on the Indonesia Stock Exchange;

$\mathrm{H}_{5}$ : Liquidity has a positive and significant effect on the profitability of manufacturing companies listed on the Indonesia Stock Exchange;

$\mathrm{H}_{6:}$ Capital structure has a positive and significant effect on the profitability of manufacturing companies listed on the Indonesia Stock Exchange;

$\mathrm{H}_{7}$ : Sales growth has a positive and significant effect on the profitability of manufacturing companies listed on the Indonesia Stock Exchange;

$\mathrm{H}_{8}$ : The role of profitability in mediating the effect of liquidity on the value of manufacturing companies listed on the Indonesia Stock Exchange;

$\mathrm{H}_{9}$ : Profitability is able to mediate the effect of capital structure on the value of manufacturing companies listed on the Indonesia Stock Exchange;

$\mathrm{H}_{10}$ : Profitability is able to mediate sales growth to the value of manufacturing companies listed on the Indonesia Stock Exchange.

\section{METHODS OF RESEARCH}

This research is a quantitative study, which departs from the positivistic paradigm. This research data is deductive in nature. This research was conducted on manufacturing companies listed on the Indonesia Stock Exchange (IDX) from 2015 to 2017. This location 
was chosen because: (1) IDX is the only Capital Market in Indonesia that trades the most complete securities, (2) Data available the IDX is complete and easily obtained, (3) the IDX data is accurate and can be justified. The population in this study was all manufacturing companies listed on the Stock Exchange in 2015 to 2017, amounting to 147 companies.

Table 2 - Data Determination Selection process

\begin{tabular}{llc}
\hline No & Criteria & Number of Companies \\
\hline 1 & All manufacturing companies listed on the Indonesia Stock Exchange & 147 \\
2 & Manufacturing companies that did not publish the data needed in full in this & 38 \\
& study, for 3 (three) consecutive years from 2015 to 2017 & 109 \\
3 & Number of companies used as research samples & \\
\hline
\end{tabular}

Source: Data Processed, 2018.

Based on Table 2, after determining the sample using purposive sampling technique obtained a sample of 109 companies. The data collection technique is done by the documentation method. Data analysis method in this research is path analysis.

\section{RESULTS AND DISCUSSION}

Structural Regression Analysis 1 is used to determine the path coefficient and its significance from the effect of the variable Liquidity (CR), Capital Structure (DAR) and Sales Growth (PP) on Profitability (ROA). Reporting the results of the analysis is presented in Table 3.

Table 3 - Reporting Regression Analysis Structure 1

\begin{tabular}{|cccc|}
\hline $\mathrm{ROA}$ & $=0,099 \mathrm{CR}$ & $-0,281 \mathrm{DAR}$ & $0,060 \mathrm{PP}$ \\
\hline $\mathrm{SE}$ & $=0,003$ & 0,010 & 0,024 \\
\hline $\mathrm{T}$ & $=1,762$ & $-4,993$ & 1,144 \\
\hline $\mathrm{Sig}$ & $=0,079$ & 0,000 & 0,253 \\
\hline $\mathrm{R}^{2}$ & $=0,110$ & $\mathrm{~F}=13,286$ & $\mathrm{Sig}=0,000$ \\
\hline
\end{tabular}

Source: Data Processed, 2018.

Reporting the results of the analysis of Regression Structure 2 is used to determine the path coefficient and its significance from the influence of the variable Liquidity $(C R)$, Capital Structure (DAR), Sales Growth (PP), and Profitability (ROA) on Firm Value (PBV). Reporting the results of the analysis is presented in Table 4.

Table 4 - Reporting Regression Analysis Structure 2

\begin{tabular}{|cccc|}
\hline $\mathrm{PBV}=-0,004 \mathrm{CR}$ & $-0,133 \mathrm{DAR}$ & $+0,018 \mathrm{PP}$ & $+0,321 \mathrm{ROA}$ \\
\hline $\mathrm{SE}=0,041$ & 0,166 & 0,401 & 0,914 \\
\hline $\mathrm{T}=-0,076$ & $-2,313$ & 0,350 & 5,879 \\
\hline $\mathrm{Sig}=0,940$ & 0,021 & 0,727 & 0,000 \\
\hline $\mathrm{R}^{2}=0,147 ;$ & $\mathrm{F}=13,831$ & & $\mathrm{Sig}=0,000$ \\
\hline
\end{tabular}

Source: Data Processed, 2018.

Based on the reporting results of Structural Regression 1 analysis in Table 3, structural equations and path coefficients of the influence of $C R$, DAR and PP variables on ROA can be made as follows:

$$
R O A=0,099 C R-0,281 D A R+0,060 P P
$$

Based on the reporting results of Structural Regression 2 analysis in Table 4, structural equation and path coefficient of influence of CR, DAR, PP, and ROA variables on PBV can be made as follows: 


$$
P B V=0,004 C R-0,133 D A R+0,133 P P+0,321 R O A
$$

From the two equations above we can determine the magnitude of the existing path coefficients, both direct effects, indirect effects and total effects as presented in Table 5.

Table 5 - Direct and Indirect Effect

\begin{tabular}{cccc}
\hline Path & Direct effect & Indirect Effect & Total Effect \\
\hline CR - PBV & $-0,003$ & 1,300 & 01.304 \\
DAR - PBV & $-0,383$ & $-3,763$ & $-3,896$ \\
PP - PBV & 0,140 & 1,144 & 1,126 \\
ROA - PBV & 5,371 & & 0,321 \\
CR - ROA & 0,004 & & 0,099 \\
DAR - ROA & $-0,049$ & & $-0,281$ \\
PP - ROA & 0,028 & & 0,060 \\
\hline
\end{tabular}

Source: Data Processed, 2018.

The Total Determination Coefficient is the total diversity of data. There is an indicator of the validity of the model that is the coefficient of total determination $\left(R^{2} m\right)$ whose interpretation is the same as the interpretation of the coefficient of determination $\left(R^{2}\right)$ in the regression analysis. To calculate the total determination coefficient $\left(R^{2} m\right)$, it is as follows.

$$
\mathrm{R}^{2}=1-\left(e_{1} \cdot e_{2}\right)
$$

The error value (ei) is calculated by the following equation:

$$
e i=\sqrt{\left(1-R^{2}\right)}
$$

Based on the $R^{2}$ value of the Structure 1 Regression equation of 0.110 and the Value of the R2 of the Structure Regression equation 2, we can calculate the value of e1 and the Total Dominated value as follows:

$$
\begin{aligned}
& e 1=\sqrt{(1-0,110)}=0,943 \\
& e 2=\sqrt{(1-0,147)}=0,923
\end{aligned}
$$

The Total Determination Coefficient values are as follows:

$$
R^{2}=0.13
$$

$R^{2}$ value of 0.13 means that the information contained in the data $13 \%$ can be explained by the model, while the rest is explained by other variables and errors.

Effect of Liquidity on the Value of Manufacturing Companies Listed on the Indonesia Stock Exchange. The results of data analysis show that liquidity has no effect on firm value. These results reject the hypothesis proposed that liquidity has a positive and significant effect on firm value. High liquidity actually makes the company have more ability to pay short-term obligations so that it is trusted by the lender, but this does not necessarily give investors confidence to be interested in buying company shares. The smooth running of short-term payments does not necessarily only benefit the company. The inefficiency of the company's operations also affects investors' views of the company. The results of this study are in line with the results of Wijaya's (2014) research that liquidity has no effect on firm value.

Effect of Capital Structure on the Value of Manufacturing Companies Listed on the Indonesia Stock Exchange. The results of data analysis show that the use of debt gives a negative signal to the value of the company. These results reject the hypothesis proposed that capital structure has a positive and significant effect on firm value. The use of debt to the company under study does not give a signal to investors that the company is trusted by 
creditors. The results of this study explain that the preference for using funding sources from within the company (internal financing) will be greater than using other funding sources such as debt and issuance of new equity. Increasing debt is seen by investors as increasing the risk of the company. Companies will get stuck in financial distress (financial difficulties), so the demand for company shares decreases, then the stock price decreases, which means the value of the company also decreases. The results of this study are in line with the results of the study of Ruan et al. (2011), Pung and Hoang (2013) show the opposite results where capital structure has a negative and significant effect on firm value.

Effect of Sales Growth on the Value of Manufacturing Companies Listed on the Indonesia Stock Exchange. The results of data analysis indicate that sales growth has not been able to be a factor that influences, on company value. These results reject the hypothesis proposed that sales growth has a positive and significant effect on firm value. Inventors are more interested in companies that have profit growth compared to companies that have sales growth but have not succeeded in increasing profits. The signal is captured by investors that company that has sales growth but does not necessarily increase the company's profit as an inefficient or wasteful company. This situation makes investors distrust the management of the company. The results of this study are in line with research by Hermuningsih (2013), Safrida (2008) which shows that sales growth has no effect on firm value.

Profitability has a Positive and Significant Impact on the Value of Manufacturing Companies Listed on the Indonesia Stock Exchange. The results of data analysis show that profitability has a positive and significant effect on firm value. These results accept the hypothesis proposed that profitability has a positive and significant effect on profitability. Good profitability in the company becomes a signal for investors to be interested in investing in the company. The more investors make investments, the increase in the company's stock price, where the stock price reflects the value of the company. The results of this study are in line with research by Anwar and Masodah (2012), Wahyuningsih (2016), Julianti (2016), Komariyah (2015) and Su'aidah (2010), which show that profitability has a positive and significant effect on firm value.

Effect of Liquidity on the Profitability of Manufacturing Companies Listed on the Indonesia Stock Exchange. The results of data analysis show that liquidity has no effect on profitability. These results reject the hypothesis proposed, that liquidity has a positive and significant effect on profitability. High liquidity makes the company have a greater ability to pay short-term obligations, so the lenders including partners and suppliers have more confidence in the company, so that it will make it easier for companies to get additional loans to smooth the company's operations. High liquidity does not necessarily increase profit. The results of this study were supported by previous similar studies conducted by Andayani (2015) who found that liquidity had no effect on profitability.

The Effect of Capital Structure on the Profitability of Manufacturing Companies Listed on the Indonesia Stock Exchange. The results of data analysis show that capital structure has a negative and significant effect on profitability. These results reject the hypothesis proposed that capital structure has a positive and significant effect on profitability. The use of debt to companies incurs debt costs such as interest fees and other administrative costs that will be charged by creditors. Increased debt costs will add to the burden of the company, which has an impact on decreasing the level of profits derived by the company. If the company's profit level decreases it can result in a decrease in the company's profitability. The results of this study are in line with the results of research conducted by Leon (2013), Pung and Hoang (2013), Quang and Xin (2014), Zakaria et al. (2014) and Christi et al. (2013) which shows that capital structure has a negative and significant effect on profitability.

Effect of Sales Growth on the Profitability of Manufacturing Companies Listed on the Indonesia Stock Exchange. The results of data analysis show that sales growth has no effect on profitability. These results reject the hypothesis proposed that sales growth has a positive and significant effect on profitability. Increased sales growth does not guarantee company profits will increase. This can happen if the company is not efficient in managing its funds, causing huge operational costs. In such circumstances sales growth is not matched by profit 
growth, as a result there is no change in company profitability. The results of this study are in line with research by Putri (2015), Safrida (2008) which shows that sales growth has no effect on profitability.

The Role of Profitability in Mediating the Effect of Liquidity on the Value of Manufacturing Companies Listed on the Indonesia Stock Exchange. Based on the sobel test results from the structure 1 regression analysis presented in table 2 and the structure 2 regression analysis presented in table 3 , profitability was found to be unable to play a role in mediating the effect of liquidity on firm value. These results reject the hypothesis proposed, that profitability plays a significant role in mediating the effect of liquidity on firm value. Based on the results of the analysis of the direct effect between liquidity on the value of the company that was carried out previously, the results had no effect, thus after adding profitability mediation variables, profitability was also unable to play a mediating role. The higher the value of the company's liquidity causes more funds available for the company to pay dividends, finance its operations and investments, so that investors' perceptions of company performance will increase. The stock price is expected to increase as well and the price to book value (PBV) will be affected favorably and increase lead to an increase in the value of the company. In this study it seems that liquidity is not able to increase profits, so profitability does not increase. This situation is a negative signal to investors, consequently not interested in owning company shares. The results of this study are in line with research by Safrida (2008) which shows that sales growth has no effect on profitability and firm value.

The Role of Profitability in Mediating the Effect of Capital Structures on the Value of Manufacturing Companies Listed on the Indonesia Stock Exchange. Based on the sobel test results from the structure 1 regression analysis presented in table 2 and the structure 2 regression analysis presented in table 3 , profitability was found to play a significant role in mediating the effect of capital structure on firm value. This result accepts the hypothesis that profitability plays a significant role in mediating the effect of capital structure on firm value. The use of debt as a measure of capital structure will increase the company's operating expenses and it will encourage a decrease in the company's profitability. The decline in corporate profits has implications for decreasing corporate profitability. The declining profitability of the company certainly affects the decline in the value of the company, because investors stare at profitability reflecting low financial performance as well, so investors are not interested in investing their funds into the company. The results of this study are in line with research conducted by Ruan et al. (2011), Pung and Hoang (2013) which show that capital structure has a negative and significant effect on profitability and firm value.

The Role of Profitability in Mediating the Effect of Sales Growth on the Value of Manufacturing Companies Listed on the Indonesia Stock Exchange. Based on the sobel test results from the structure 1 regression analysis presented in table 2 and the structure 2 regression analysis presented in table 3 , profitability was found to be unable to play a role in mediating the effect of capital sales growth on firm value. These results reject the proposed hypothesis, that profitability plays a significant role in mediating the effect of sales growth on firm value. Sales growth reflects the company's achievements in the past, sales growth is used to predict the company's achievements in the future. Sales growth can also show the company's competitiveness in the market increased positive company sales growth and increasing, it will indicate a large company value, which is the expectation of the company owner. Investors use sales growth as an indicator to see the prospects of the company they will invest in later. This research seems that sales growth does not increase profits, so profitability does not increase. This situation gives a negative signal to investors; as a result investors are not interested in having company shares. The results of this study are in line with research by Safrida (2008) which shows that sales growth has no effect on profitability and firm value.

\section{CONCLUSION}

Based on the discussion and description in the previous chapters, it can be concluded that liquidity has no effect on firm value. Capital structure has a negative and significant 
effect on firm value. Sales growth has no effect on firm value. Profitability has a positive and significant effect on firm value. Liquidity does not affect profitability. Capital structure has a negative and significant effect on profitability. Sales growth does not affect profitability. Profitability does not play a role in mediating the effect of liquidity on firm value. Profitability is able to mediate the effect of capital structure on firm value. Profitability is not able to play a role in mediating the effect of sales growth on firm value. Based on the description above, the advice that can be given is for the company to strengthen its financial performance in order to attract investors to choose the company as their investment destination. Companies should continue to maintain their capital structure, namely the balance between debt and equity, because from the results of research it is proven that capital structure influences financial performance and firm value. Good communication and cooperation with suppliers and partners is needed, so that it still makes it easy for companies to get short-term debt. Suggestions for further researchers need to consider conducting a more detailed analysis for other sectors outside the manufacturing company. For the sake of academic studies, the next researcher needs to consider further research by adding other variables such as interest rate dividend and inflation policies that have not been included in this study in order to broaden and deepen this research. In order to get a comparison of results researchers are expected to add to the research period or change the sample used.

\section{REFERENCES}

1. Akhtar, S. \& Liu, Y. 2018. SMEs' Use of Financial Statements for Decision Making: Evidence from Pakistan. Journal of Applied Business Research, 34(2), 381 - 392. DOI:10.19030/jabr.v34i2.10138.

2. Anwar, D. O. and Masodah, Dan. 2012. Pengaruh Kinerja Keuangan Terhadap Nilai Perusahaan Dengan Pengungkapan Corporate Social Responsibility and Kepemilikan Manjerial Sebagai Variabel Pemoderasi. Jakarta: Universitas Gunadarma.

3. Arif, I. A. I. 2018. Keputusan Struktur Modal, Faktor Determinan and Dampaknya Pada Nilai Perusahaan: Studi Komparatif Antara Perusahaan Manufaktur Syariah and Non Syariah. $9^{\text {th }}$ Industrial Research Workshop and National Seminar.

4. Babu, S., Jain, K. 1998. Empirical Testing of Pecking Order Hypothesis with Reference to Capital Structure Practices in India. Journal of Financial Management \& Analysis. JulyDecember: 63-74.

5. Bachimeg, B. 2017. Financial Performance Determinants of Organizations: The Case of Mongolian Companies. Journal of Competitiveness, 9(3), $22-33$.

6. Badan Koordinasi Penanaman Modal. Industri Manufaktur di Indonesia Sebagai Basis Produksi di ASEAN. https://www.investindonesia.go.id/id/artikelinvestasi/detail/perkembangan-industri-manufaktur-di-indonesia, diakses pada 15 Oktober 2019.

7. Brigham, E.F., Daves, P.R. 2016. Intermediate Financial Management. $12^{\text {th }}$ Edition. Thomson Higher Education, 5191 Natorp Boulevard, Mason, OH 45040 USA.

8. Cipto, P. K. A., Choerudin, A., \& Suryanti, Y. 2019. The Factors That Affecting Structure Capital in Manufacturing Companies: The Study in Indonesia of 2012 - 2014. International Journal of Information, Business and Management, 11(3), $227-234$.

9. Durrah, O., Rahman, A. A. A., Jamil, S. A., Ghafeer, N. A. 2016. Exploring the Relationship between Liquidity Ratios and Indicators of Financial Performance: An Analytical Study on Food Industrial Companies Listed in Amman Bursa. International Journal of Economics and Financial Issues, 6(2), $435-441$.

10. Ebrati, M. R., Emadi, F., Balasang, R. S., \& Safari, G. 2013. The Impact of Capital Structure on Firm Performance: Evidence from Tehran Stock Exchange. Australian Journal of Basic and Applied Sciences, 7(4), 1-8. ISSN 1991-8178.

11. Fajriati, B. 2017. Analisis Faktor - Faktor Yang Mempengaruhi Struktur Modal and Pengaruh Struktur Modal Terhadap Return Saham (Studi Empiris Pada Perusahaan Perbankan di Bursa Efek Indonesia). Warta Ekonomi, 7(17), 1 - 19.

12. Harmono. 2015. Manajemen Keuangan Berbasis Balance Scorecard Pendekatan Teori, 
Kasus, and Riset Bisnis. Jakarta: Bumi Aksara.

13. Hedau, A., Singh, S., \& Janor, H. 2018. Determinants of Capital Structure - A Sector Specific Approach. Romanian Economics and Business Review, 13(4), 14 - 30.

14. Hery. 2015. Analisis Laporan Keuangan. Yogyakarta: CAPS.

15. Janjua, A. R., Asghar, A., Umais, M., Raza, A., \& Akhtar, M. 2016. Influence of Liquidity on Profitability of Cement Sector: Indication from Firms Listed in Pakistan Stock Exchage. Business Management Dynamic, 6(5), 112.

16. Julianti, D. K. 2015. Pengaruh Mekanisme Good Corporate Governance Terhadap Nilai Perusahaan dengan Profitabilitas Sebagai Variabel Intervening pada Perusahaan Manufaktur yang Terdaftar di BEI Tahun 2010 - 2013. Skripsi Universitas Negeri Semarang.

17. Kasmir. 2014. Analisis Laporan Keuangan. Jakarta: PT. Raja Grafindo Persada.

18. Kementrian Perindustrian Republik Indonesia. Kontribusi Industri Manufaktur Indonesia Peringkat Kempat Dunia. https://www.kemenperin.go.id/artikel/18325/Kontribusi-IndustriManufaktur Indonesia-Peringkat-Keempat-Dunia, diakes pada 15 Oktober 2019.

19. Keown, A. J., Titman, S. \& Martin, J. D. 2011. Financial Management: Principles and Applications, Eleventh Edition ISBN-13: 978-0-13-216589-1 ISBN-10: 0-13-2165899Publisher: PH Professional Business.

20. Lamuda, I. 2017. The Effects of Firm Size and Profitability on Banking Industry: Evidence from Indonesia Stock Exchange. Journal of Economics and Management Perspective, $11(4), 1214-1220$.

21. Leon, S. A. J. 2013. The Impact of Capital Structure on Financial Performance of The Listed Manufacturing Firms in Sri Lanka. Global Journal of Commerce and Management Perspective, 2(5), $56-62$.

22. Lubis, I. L., Sinaga, B. M, \& Sasongko, H. 2017. Pengaruh Profitabilitas, Struktur Modal, and Likuiditas Terhadap Nilai Perusahaan. Jurnal Aplikasi Bisnis and Manajemen, 3(3), 458 - 465. DOI: 10.17358/jabm.3.3.458.

23. Mahmudi, S. \& Mohammadi, H. 2015. The Relationship Between the Capital Structure and the Performance of the Firms Listed in the Tehran Stock Exchange. Journal of Scientific Research and Development. 2(1), 208-216.

24. Modigliani, F. \& Miller, M. 1963. Corporate Income Taxses and the Cost of Capital: A Correction. American Economic Review, 53(3), 433-443. http://www.jstor.org/stable/1809167.

25. Mujahid, M., Akhtar, K., \& Bahawalpur. 2014. Impact of Capital Structure on Firms Financial Performance and Shareholders Wealth: Textile Sector of Pakistan. International Journal of Learning \& Development, 4(2), 2164 -4063.

26. Negasa, T. 2016. The Effect of Capital Structure on Firms' Profitability. Evidenced from Ethiopian. Reprints, 1 - 9. DOI:10.20944/preprints201607.0013.v1

27. Republik Indonesia. 1995. Undang-Undang No. 8 Tahun 1995 tentang Pasar Modal.

28. Singh, D. 2016. A Panel Data Analysis of Capital Structure Determinants: an Empirical Study of Non-Financial Firms in Oman. International Journal of Economics and Financial Issues, 6(4), 1650 - 1656.

29. Sinha, A. 2017. An Enquiry into Effect of Capital Structure on Firm Value: A Study of Power Sector Companies in India. KIIT Journal of Management, 13(2), $107-117$. DOI:10.23862/kiit-parikalpana/2017/v13/i2/164525.

30. Su'aidah, S. 2010. Pengaruh ROA and ROE Terhadap Nilai Perusahaan Dengan Pengungkapan Corporate Social Responsibility and Kepemilikan Manajerial Sebagai Variabel Pemoderasi. Skripsi. Sekolah Tinggi Ilmu Ekonomi Perbanas Surabaya.

31. UU Pasar Modal No. 8 Tahun 1995 tentang Bursa Efek Indonesia (BEI).

32. Wahyuningsih, 2016. Pengaruh Struktur Kepemilikan, Kebijakan Keuangan, and Intangible Asset Value Terhadap Nilai Perusahaan (Studi Empiris Pada Perusahaan Manufaktur Di Bursa Efek Indonesia Tahun 2011-2014). Universitas Muhammadiyah.

33. Yuniari, N. P \& Badjra, I. B. 2019. Pengaruh Likuiditas, Efisiensi, and Ukuran Bank Terhadap Profitabilitas. E-Jurnal Manajemen, 8(6), 3502 - 3530. DOI: https://doi.org/10.24843/EJMUNUD.2019.v08.i06.p08. 